Research Article

\title{
Effect of Tillage Treatments of Hairy Vetch Residues on Soil Inorganic-N Distributions and Corn Growth in a Subtropical Region
}

\author{
Fajri Anugroho $\mathbb{D}^{1}$ and Makoto Kitou ${ }^{2}$ \\ ${ }^{1}$ Department of Agricultural Engineering, Faculty of Agricultural Technology, University of Brawijaya, Veteran Street, \\ Malang 65145, Indonesia \\ ${ }^{2}$ Faculty of Agriculture, University of the Ryukyus, Senbaru 1, Nishihara, Okinawa 903-0213, Japan
}

Correspondence should be addressed to Fajri Anugroho; fajri.anugroho@gmail.com

Received 8 August 2019; Accepted 5 March 2020; Published 31 March 2020

Academic Editor: Claudio Cocozza

Copyright (c) 2020 Fajri Anugroho and Makoto Kitou. This is an open access article distributed under the Creative Commons Attribution License, which permits unrestricted use, distribution, and reproduction in any medium, provided the original work is properly cited.

\begin{abstract}
Conservation tillage has many advantages in crop production and weed control management. N-residue of hairy vetch as a green manure cover crop through tillage and no-tillage practices may increase inorganic-N level in soils and contribute to sustainable agriculture. Prior to corn cultivation, hairy vetch was cut after growing in the pots for 103 days. Six treated soils were prepared for no-tillage treatments (SRN, RN, and CN) and for tillage treatments (SRT, RT, and CT), where the soils were treated by shoot and root of hairy vetch residues, only root residues, and without application of hairy vetch as a control, respectively. Seeds of corn (Zea mays L.) were sown and grown for 56 days after sowing. The shoot and root biomasses of corn under no-tillage were higher than those of tillage. Furthermore, the shoot biomass of corn in both SRN and SRT were higher than that in other treatments. The root biomass of corn was higher in upper layers $(0-5 \mathrm{~cm}$ depth) and deeper layers $(>10 \mathrm{~cm}$ depth) than in middle layers $(5-10 \mathrm{~cm}$ depth) of soils. In the upper layer, the $\mathrm{NH}_{4}-\mathrm{N}$ contents of no-tillage were higher at 9 and $23 \mathrm{DAT}$ than those of tillage. The $\mathrm{NH}_{4}-\mathrm{N}$ content of the soils for no-tillage in the middle layer and the deeper layer was lower than that of the CT treatment. The $\mathrm{NO}_{3}-\mathrm{N}$ content of no-tillage in the middle and deeper layers was lower than that of CT at 23 and 65 DAT. N-uptake of corn in both notillage and tillage treatments with hairy vetch addition was higher than that of the control.
\end{abstract}

\section{Introduction}

In recent years, there has been increasing attention paid to tillage operation for crop production in tropical and subtropical regions. Tillage systems are separated into two types as conservation tillage and conventional tillage, where conservation tillage included no-tillage which has many advantages in the crop production system[1] and weed control management [2]. In contrast, conventional tillage may cause tons of nutrients which are dissolved and transported with runoff sediments from the agricultural land annually [3]. High decomposition rates of soil organic matter associated with degradation processes which is accelerated by tillage operation in cultivated soils present a very disturbing problem. Soil organic matter in the tropics decomposes five times faster than in temperate regions [4].

Hairy vetch, as a preferred winter legume cover crop in subtropical regions to suppress weeds in the agricultural field, has been well documented $[5,6]$. Moreover, the percentage of weed suppression was 63, compared with the fallow soil, which has been reported previously [6]. It was probably due to the light competition [7] and the allelophatic compounds $[8,9]$. Biological $\mathrm{N}$ fixation reduced the application of $\mathrm{N}$ fertilizers for subsequent crops [10-12]. Furthermore, N supply by shoot and root of hairy vetch through tillage and no-tillage systems may increase inorganic- $\mathrm{N}$ level in soils and contribute to better agronomic practices for sustainable agriculture. The advantages of including hairy vetch as cover crops into corn and sorghum 
production systems are well documented for the subtropical and temperate region of Japan $[6,13]$; however, the distribution of the ammonium-N and nitrate- $\mathrm{N}$ in the soil depths and the effect on the growth of the shoot and root of corn are not well understood.

The objectives of this study were to observe the biomass and nutrient accumulation of the shoot and root of hairy vetch which is applied as green manure for the growth of subsequent corn. Another attempt is to determine ammonium and nitrate levels of different soil depths after hairy vetch addition and their effects on corn growth.

\section{Materials and Methods}

2.1. Soil Properties. $\mathrm{pH}$ and electrical conductivity of the initial red soil were 5.0 and $9.8 \times 10^{-3} \mathrm{~S} \mathrm{~m}^{-1}$, respectively. Total $\mathrm{C}$, total $\mathrm{N}, \mathrm{C} / \mathrm{N}$ ratio, inorganic $\mathrm{N}$, and phosphate absorption coefficients were $1.3 \mathrm{~g} \mathrm{~kg}^{-1}, 0.3 \mathrm{~g} \mathrm{~kg}^{-1}, 5.1$, $3.1 \mathrm{mg} \mathrm{kg}^{-1}$, and $4.1 \mathrm{~g} \mathrm{~kg}^{-1}$, respectively.

2.2. Experimental Setup. The soils in $0.02 \mathrm{~m}^{2}$ pots used in this study were previously cultivated by hairy vetch (Vicia villosa Roth cv. Mameko, Kaneko Syubyo). Moreover, the soils in some pots were without cultivation of hairy vetch as a control treatment. In the cultivation pots, a shoot part of hairy vetch was cut at the soil surface and removed from the pots, while a root part of hairy vetch still remained in the soils. All shoots of hairy vetch were sampled, cut in $2-3 \mathrm{~cm}$ length, and used as organic input materials for corn cultivation. Prior to planting corn, the fertilizers with a rate of $1.0 \mathrm{~g} \mathrm{~N}, 0.5 \mathrm{~g} \mathrm{P}_{2} \mathrm{O}_{5}$, and $0.5 \mathrm{~g} \mathrm{~K}_{2} \mathrm{O}$ were applied together with preparing six treatments as follows. Fourteen grams of the dried cut-shoots and fertilizer were applied and tilled with the soil-containing roots (SRT), and the other one was put on the surface of the soil-containing roots as mulch or notillage $(\mathrm{SRN})$. The soils containing roots were also added fertilizer with tillage (RT) and without tillage (RN). Similarly, pots without hairy vetch addition were treated by tillage (CT) and no-tillage $(\mathrm{CN})$ as the control. There were two pot-conditions. One was planted-corn pots for plant growth measurement and another was without corn for determining soil chemical properties. Soils were tilled on 10 March. Three seeds of corn (Zea mays L.) were sown in each pot on 7 April. Shoots and roots of corn were harvested on 2 June (at 56 days after sowing). Soils were sampled at three soil depths $(0-5 \mathrm{~cm}, 5-10 \mathrm{~cm}$, and more than $10 \mathrm{~cm})$ and three times on 19 March ( 9 days after tillage/DAT), 2 April (23 DAT), and 12 May (65 DAT). The measurements were performed with three replications.

2.3. Plant and Soil Analysis. The shoot and root samples were dried at $70^{\circ} \mathrm{C}$ for $72 \mathrm{~h}$, weighed, and powdered prior to chemical analysis. Total $\mathrm{C}$ and $\mathrm{N}$ concentrations were determined by CHN Coder (JM10, G-Science, Lab. Co., Ltd., Japan). Total $\mathrm{P}$ concentration was determined by calorimetric methods after drying the ash at $450^{\circ} \mathrm{C}$ for $1 \mathrm{~h}$ and dissolving it in $1: 30(\mathrm{v} / \mathrm{v})$ diluted nitric acid [14]. The concentrations of $\mathrm{K}, \mathrm{Ca}$, and $\mathrm{Mg}$ of all samples were determined using an atomic absorption spectrophotometer (AAS) (Solaar 969; Japan Thermo Corp., Tokyo, Japan) after Kjeldahl degradation. The soils were air-dried and passed through a $2 \mathrm{~mm}$ sieve. The soil $\mathrm{pH}$ and $\mathrm{EC}$ were measured in water at $1: 2.5$ and $1: 5(\mathrm{w} / \mathrm{v})$, respectively. The total C and $\mathrm{N}$ concentrations were determined using a CHN coder (JM10; G-Science Laboratory Company, Tokyo, Japan). The inorganic nitrogen was determined by steam distillation after extraction with $2 \mathrm{~mol} \mathrm{~L}^{-1} \mathrm{KCl}$ ([15]). Ca-bound phosphate, as available $\mathrm{P}_{2} \mathrm{O}_{5}$, was determined by calorimetric methods after extraction with $0.025 \mathrm{~L} \mathrm{~L}^{-1}$ of acetic acid. The phosphate absorption coefficient was determined by calorimetric methods after absorption with ammonium hydrogen phosphate. The exchangeable cations were determined by AAS after extraction with ammonium acetate.

2.4. Statistical Analysis. The data are the mean values of three replicates with the standard error of the mean. The mean values of the data were compared by one-way analysis of variance (ANOVA) with a completely randomize design. The mean comparisons were evaluated using Fisher's protected least significant difference (LSD) test at $p<0.05$. Statistical procedures were carried out with the software package SPSS 14.0 for windows.

\section{Results}

3.1. Nutrient from Hairy Vetch. Shoot and root residue from hairy vetch which applied was 14.0 and $10.0 \mathrm{~g} \mathrm{DW} \mathrm{pot}^{-1}$, respectively. Total biomass addition of hairy vetch was $24 \mathrm{~g}$ DW pot $^{-1}$ which may supply some nutrients by releasing them through decomposition. The total biomass addition of hairy vetch might be associated with the nutrient input (mg pot $^{-1}$ ) of 955.0 N, 77.6 P, and 147.6 K (Table 1). In addition, the nutrients for corn growth were not only derived from decomposing of hairy vetch but also from fertilizers that were applied at the same time. They were taken up by corn during its vegetative growth.

3.2. Ammonium-N and Nitrate-N Distribution. The ammonium- $\mathrm{N}\left(\mathrm{NH}_{4}-\mathrm{N}\right)$ content in the upper $(0-5 \mathrm{~cm}$ depth), middle $(5-10 \mathrm{~cm}$ depth), and deeper layers $(>10 \mathrm{~cm}$ depth) of the soils for no-tillage and tillage treatments showed was decreased during the growing period of corn (Figure 1(a)$1(\mathrm{c}))$. In the upper layer $(0-5 \mathrm{~cm}$ depth) of the soils, the $\mathrm{NH}_{4}-\mathrm{N}$ content at 9 and 23 days after treatment (DAT) for no-tillage was higher than for tillage. The $\mathrm{NH}_{4}-\mathrm{N}$ content in the upper layer of the soils showed higher for the shoot and root additions of tillage than for root addition and control of tillage. In the middle and deeper layers of the soils, the $\mathrm{NH}_{4}$ $\mathrm{N}$ content of the soils at $9 \mathrm{DAT}$ was lower for no-tillage than that for tillage. Nitrate-N $\left(\mathrm{NO}_{3}-\mathrm{N}\right)$ in all layers of the soils for no-tillage and tillage treatments was increased during the growing period of corn (Figure $1(\mathrm{~d})-1(\mathrm{f})$ ). The $\mathrm{NO}_{3}-\mathrm{N}$ content in all layers of the soil at 9 DAT showed a similar content and higher in the control of tillage (CT), but it was lower at 23 DAT and 65 DAT for no-tillage than for tillage. The $\mathrm{NO}_{3}-\mathrm{N}$ content in the upper layer of the soils showed 
TABLE 1: Nutrient containing in the hairy vetch (HV) residues and the fertilizer.

\begin{tabular}{lccc}
\hline & & Nutrient $\left(\mathrm{mg} \mathrm{pot}^{-1}\right)$ & Fertilizer \\
\hline Nitrogen (N) & Shoot HV & Root HV & 1000.0 \\
Phosphorus (P) & 591.4 & 363.6 & 109.1 \\
Potassium (K) & 45.5 & 32.1 & 207.5 \\
\hline
\end{tabular}

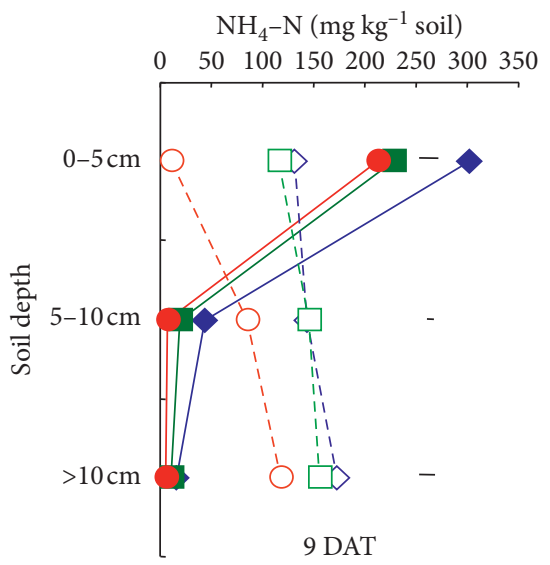

SRN: shoot + root in no-tillage

RN: root in no-tillage

- CN: control in no-tillage

$\checkmark$ SRT: shoot + root in tillage

$-\square-$ RT: root in tillage

$-\bigcirc-\mathrm{CT}$ : control in tillage

(a)

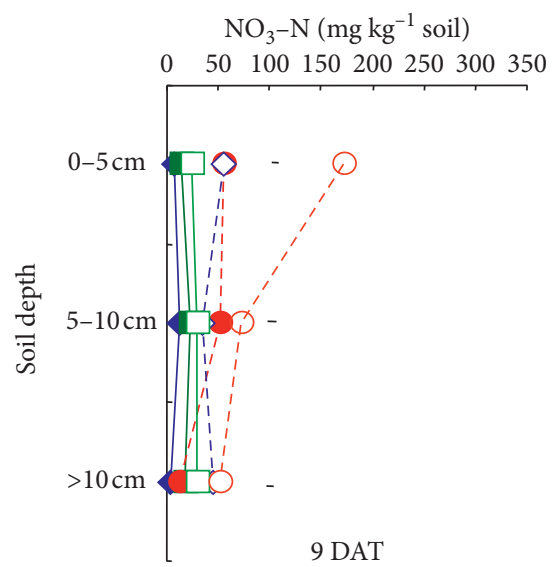

SRN: shoot + root in no-tillage

RN: root in no-tillage

CN: control in no-tillage

$\checkmark$ SRT: shoot + root in tillage

$-\square$ RT: root in tillage

$-\bigcirc-C T$ : control in tillage

(d)

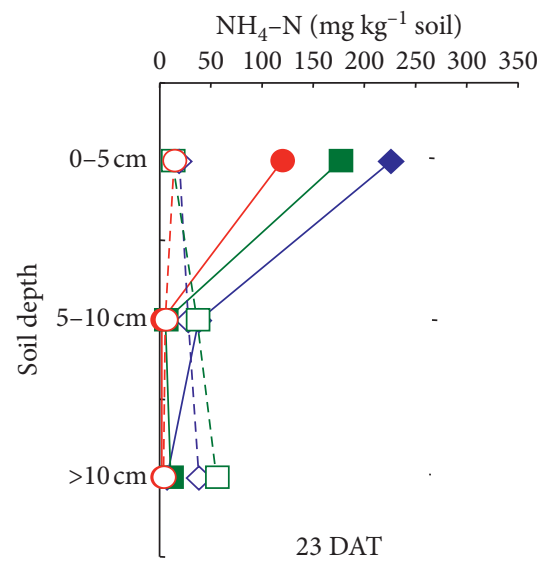

SRN: shoot + root in no-tillage

RN: root in no-tillage

- $\mathrm{CN}$ : control in no-tillage

$\checkmark$ SRT: shoot + root in tillage

$-\square-$ RT: root in tillage

-O- CT: control in tillage

(b)

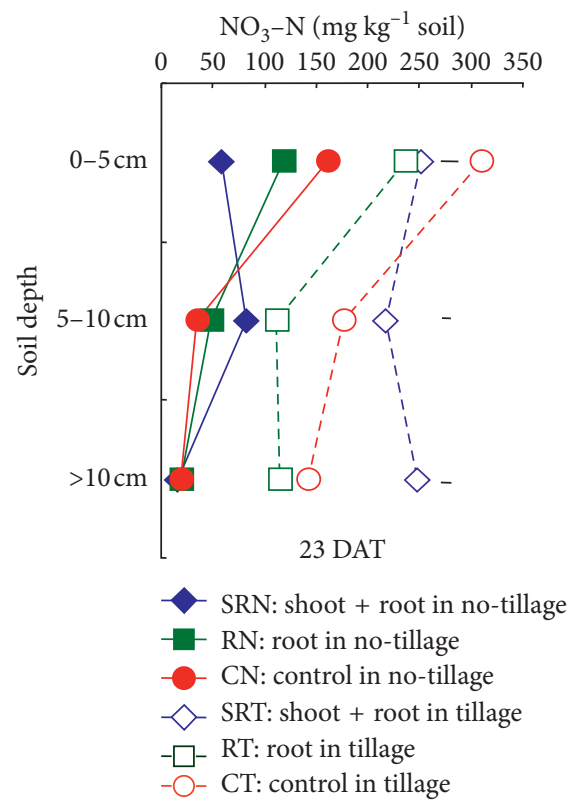

(e)

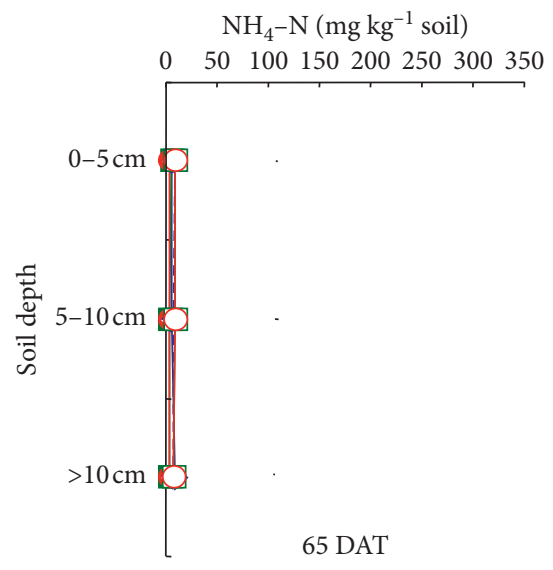

SRN: shoot + root in no-tillage

RN: root in no-tillage

- $\mathrm{CN}$ : control in no-tillage

$\checkmark$ SRT: shoot + root in tillage

- $\square$ - RT: root in tillage

$-\mathrm{O}-\mathrm{CT}$ : control in tillage

(c)

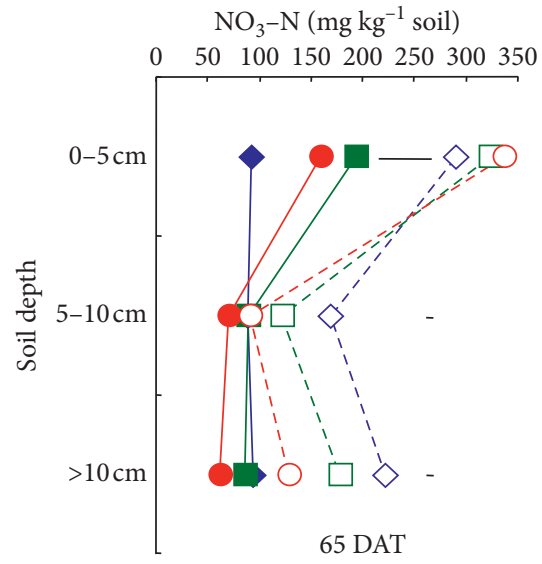

SRN: shoot + root in no-tillage

$\mathrm{RN}$ : root in no-tillage

$\mathrm{CN}$ : control in no-tillage $\checkmark$ SRT: shoot + root in tillage

$-\square$ - RT: root in tillage

-O- CT: control in tillage

(f)

Figure 1: Ammonium-N and nitrate-N levels distributed in three soil depths $(0-5 \mathrm{~cm}, 5-10 \mathrm{~cm}$, and $>10 \mathrm{~cm})$ at 9,23 , and 65 days after treatment (in absence of corn), shoot and root addition (SRN and SRT), root addition (RN and RT) and without hairy vetch addition in notillage $(\mathrm{CN})$ and tillage $(\mathrm{CT})$. Vertical bars represent LSD $(p<0.05)$. 
was lower for the shoot and root additions of tillage than for root addition and control of tillage.

3.3. Plant Height and Shoot and Root Biomass of Corn. During the growing period of corn, $\mathrm{N}$ was supplied from the $\mathrm{N}$ fertilizer and hairy vetch residue in no-tillage and tillage. Plant height of corn during 14 to 56 DAT under SRN and RN treatments had a tendency to be higher than under $\mathrm{CN}$ treatment in no-tillage and higher than SRT, RT, and CT treatments in the tillage system (Figure 2). In addition, the presence of hairy vetch residues in no-tillage showed the wider stem diameters of corn from the first growing period and more light-green leaves during 42-56 DAT than that in tillage. The plant height of corn under $\mathrm{CN}$ showed a similar level with addition of hairy vetch in tillage and tended to be higher than CT. However, the plant height of corn treated with hairy vetch in no-tillage and tillage was relatively higher than that in the control.

The shoot and root biomass of corn under no-tillage was higher than tillage (Figures 3 and 4). Furthermore, the shoot biomass of corn under SRN was tended to be higher than RN. Similarly, it was higher under $\mathrm{RN}$ than $\mathrm{CN}$ in no-tillage. Meanwhile, the shoot biomass of corn under SRT was lower than SRN and RN. In addition, the shoot biomass of corn under $\mathrm{CN}$ was relatively higher than that under CT. Root biomass of corn at three soil depths had a similar pattern with the shoot biomass. The distribution of the root biomass was higher in the upper and the deeper layers than in the middle layer.

\section{Discussion}

In the present pot experiment, hairy vetch grown under red soil was flowered in February, similar with the previous study $[5,16]$ but earlier compared with the data reported in the temperate region [13]. The biomass dry weight of shoots and roots of hairy vetch was obtained higher than that of hairy vetch [13]. Percentages of hairy vetch biomass additions by shoots 60 and roots 100, compared with their initial biomass, were input as green manure into soils under notillage and tillage together with secondary fertilizer applications for the vegetative growth of corn. The combination of $\mathrm{N}$ from the fertilizer and the cover crop into an integrated organic- $\mathrm{N}$ and inorganic- $\mathrm{N}$ management system could realize the positive benefits of each source in corn production [17]; the percentage of $\mathrm{N}$ recovery of hairy vetch residues and $\mathrm{N}$ fertilizer in the soil was 55 and 27, respectively. The fertilizer may satisfy to supply the major nutritional needs of the crop and the cover crop residues contributing more $\mathrm{N}$ for maintaining soil $\mathrm{N}$ resources.

The additional biomass of the shoots and roots in notillage and tillage affected the ammonium- $\mathrm{N}$ and nitrate- $\mathrm{N}$ contents in the soil profiles. The ammonium content of soils was declined and converted to the nitrate- $\mathrm{N}$ content during 9 to 65 DAT in no-tillage and tillage. It was presumably due to the mineralization which was higher rather than immobilization. The high mineralization occurred in the tillage rather than in no-tillage. Tillage influences the mineralization of the cover crop residue and the soil $\mathrm{N}$ level [18].

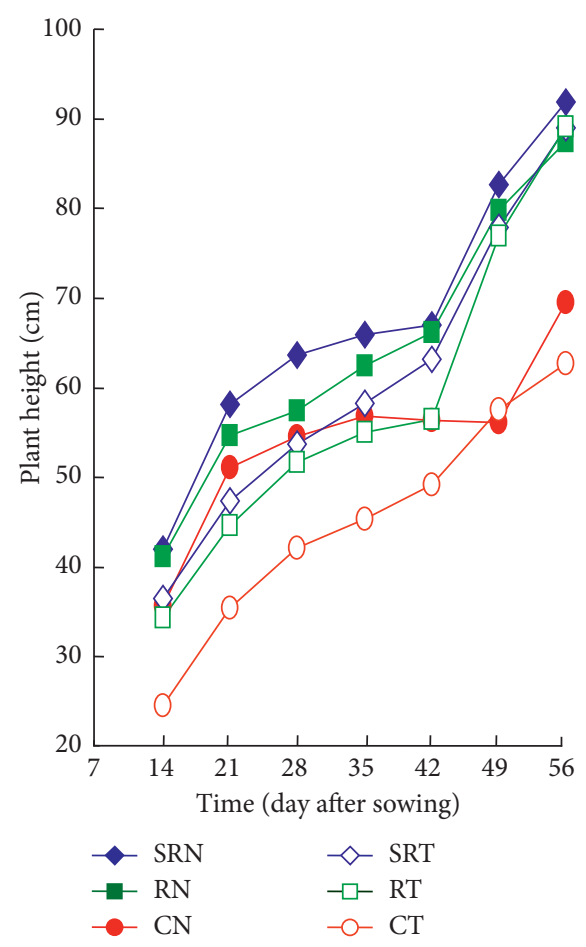

Figure 2: Plant height maize from 14 to 56 DAT $(n=3)$.

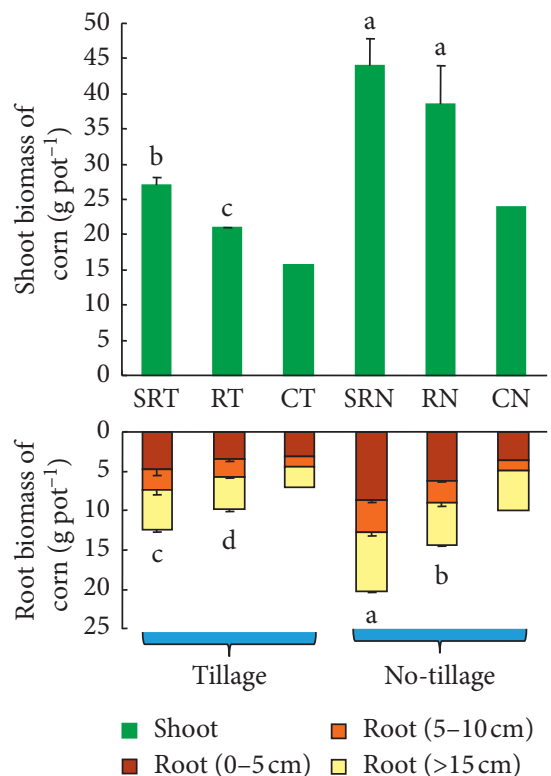

Figure 3: Shoot and root biomass of corn at 56 DAT. The different numbers show a significant difference according to the least significant difference at $p<0.05(n=3)$.

The ammonium-N content was highly concentrated in the upper layer for no-tillage, in contrast with tillage at 9 DAT. It was probably due to the different distributions of the ammonium-N content, where the hairy vetch residue and $\mathrm{N}$ fertilizer were initially placed at the upper layer in no-tillage, in contrast with tillage. In addition, the release of mineralized $\mathrm{N}$ following degradation of the tilled cover crop residue depends on the quantity of the residue, tissue $\mathrm{N}$ concentration, or $\mathrm{C} / \mathrm{N}$ 

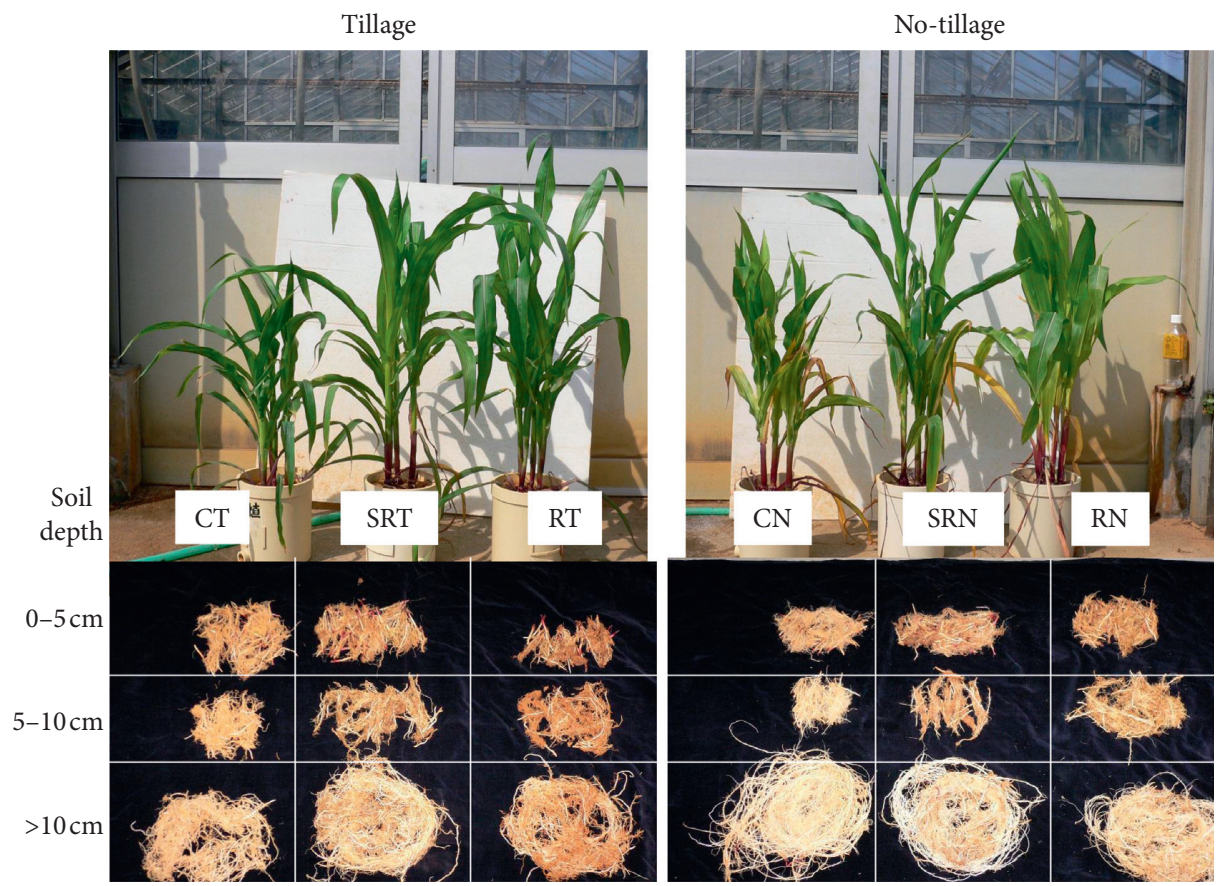

FIgURE 4: Corn growth on the pot experiment with tillage and no-tillage at 56 DAT. CT without addition (as the control) for tillage. SRT: shoot-root addition with tillage; CN: without addition (as the control) for no-tillage. SRN: shoot-root addition with no-tillage; RN: root addition with no tillage.

ratio [11]. Generally, the nitrate-N content of the soil layers in no-tillage was lower than in tillage during 9 to 65 DAT. It may indicate that the release of the nitrate- $\mathrm{N}$ content in the notillage was slower than that in tillage. Moreover, the $\mathrm{N}$ loss in the tillage system was varied in the range of $42-48 \%$ through leaching and denitrification [17].

Corn height was highly affected by the shoots and roots of hairy vetch addition in no-tillage rather than that in tillage. Corn height was increased during 14 to 42 DAT related to the increase of the nitrate- $\mathrm{N}$ content of the soils during 23 to 65 DAT. Similarly, the biomass dry weight of shoots and roots of corn was higher in the no-tillage than that in tillage. This is consistent with the previous study which reported that the corn growth was higher when cultivated in the presence of hairy vetch with zero tillage than tillage and natural fallow [6].

\section{Conclusion}

Under no-tillage, the shoot and root growth of corn was significantly higher for the shoot and root addition than for the absence of hairy vetch and tillage treatments. Even though the hairy vetch residue of no-tillage that was decomposed slower and slowly released nutrient into the soils than that of tillage, the high $\mathrm{NH}_{4}-\mathrm{N}$ and $\mathrm{NO}_{3}-\mathrm{N}$ contents for tillage might be lost by leaching and denitrification more rapidly than for no-tillage. Therefore, the high nitrate- $\mathrm{N}$ release in tillage may able to leach into the ground and cause a more serious problem rather than for no-tillage. Further field study is needed to evaluate the effects of hairy vetch addition and no-tillage on soil $\mathrm{N}$ availability and yield production of corn.

\section{Data Availability}

The data used to support the findings of this study are available from the corresponding author upon request.

\section{Conflicts of Interest}

The authors declare that they have no conflicts of interest.

\section{Acknowledgments}

This research was a part of the study in Kagoshima University with support by the Ministry of Education, Culture, Sports, Science and Technology (Monbukagakusho), Japan. The authors thank their colleagues from Laboratory of Soil Science and Plant Nutrition, University of the Ryukyus, who provided insight and expertise that greatly assisted the research.

\section{References}

[1] J. Peigné, B. C. Ball, J. Roger-Estrade, and C. David, "Is conservation tillage suitable for organic farming? A review," Soil Use and Management, vol. 23, no. 2, pp. 129-144, 2007.

[2] J. Hiltbrunner, M. Liedgens, L. Bloch, P. Stamp, and B. Streit, "Legume cover crops as living mulches for winter wheat: components of biomass and the control of weeds," European Journal of Agronomy, vol. 26, no. 1, pp. 21-29, 2007.

[3] D. J. Oyedele and P. O. Aina, "A study of soil factors in relation to erosion and yield of maize on a Nigerian soil," Soil and Tillage Research, vol. 48, no. 1-2, pp. 115-125, 1998.

[4] P. A. Sanchez and T. J. Logan, "Myths and science about the chemistry and fertility of soils in the tropics," in In Myths and Science of Soils of the Tropics, R. By Lal and P. A. Sanchez, Eds., 
pp. 35-46, Soil Science Society of America, Madison, WI, USA, 1992.

[5] F. Anugroho, M. Kitou, F. Nagumo, K. Kinjo, and Y. Tokashiki, "Effect of the sowing date on the growth of hairy vetch (Vicia villosa) as a cover crop influenced the weed biomass and soil chemical properties in a subtropical region," Weed Biology and Management, vol. 9, no. 2, pp. 129-136, 2009.

[6] R. Zougmoré, F. Nagumo, and A. Hosikawa, "Nutrient uptakes and maize productivity as affected by tillage system and cover crops in a subtropical climate at Ishigaki, Okinawa, Japan," Soil Science and Plant Nutrition, vol. 52, no. 4, pp. 509-518, 2006.

[7] J. R. Teasdale, "Reduced-herbicide weed management systems for no-tillage corn (Zea mays) in a hairy vetch (Vicia villosa) cover crop," Weed Technology, vol. 7, no. 4, pp. 879-883, 1993.

[8] E. C. Hill, M. Ngouajio, and M. G. Nair, "Allelopathic potential of hairy vetch (Vicia villosa) and cowpea (Vigna unguiculata) methanol and ethyl acetate extracts on weeds and vegetables," Weed Technology, vol. 21, no. 2, pp. 437-444, 2007.

[9] J. R. Teasdale and C. S. T. Daughtry, "Weed suppression by live and desiccated hairy vetch (Vicia villosa)," Weed Science, vol. 41, no. 2, pp. 207-212, 1993.

[10] A. J. Clark, A. M. Decker, J. J. Meisinger, F. R. Mulford, and M. S. McIntosh, "Hairy vetch kill date effects on soil water and corn production," Agronomy Journal, vol. 87, no. 3, pp. 579-585, 1995.

[11] S. Kuo and E. J. Jellum, "Influence of winter cover crop and residue management on soil nitrogen availability and corn," Agronomy Journal, vol. 94, no. 3, pp. 501-508, 2002.

[12] K. A. McVay, D. E. Radcliffe, and W. L. Hargrove, "Winter legume effects on soil properties and nitrogen fertilizer requirements," Soil Science Society of America Journal, vol. 53, no. 6, pp. 1856-1862, 1989.

[13] B. Choi and H. Daimon, "Effect of hairy vetch incorporated as green manure on growth and N uptake of sorghum crop," Plant Production Science, vol. 11, no. 2, pp. 211-216, 2008.

[14] H. Hafner, E. George, A. Bationo, and H. Marschner, "Effect of crop residues on root growth and phosphorus acquisition of pearl millet in an acid sandy soil in Niger," Plant and Soil, vol. 150, no. 1, pp. 117-127, 1993.

[15] R. L. Mulvaney, "Nitrogen-inorganic forms," in Methods of Soil Analysis, Part 3, Soil Science Society of America Book Ser. 5, D. L. Sparks et al., Ed., pp. 1123-1184, Soil Science Society of America, Madison, WI, USA, 1996.

[16] F. Anugroho, M. Kitou, F. Nagumo, K. Kinjo, and Y. Tokashiki, "Growth, nitrogen fixation, and nutrient uptake of hairy vetch as a cover crop in a subtropical region," Weed Biology and Management, vol. 9, no. 1, pp. 63-71, 2009.

[17] J.-H. Seo, J. J. Meisinger, and H.-J. Lee, "Recovery of nitrogen15-labeled hairy vetch and fertilizer applied to corn," Agronomy Journal, vol. 98, no. 2, pp. 245-254, 2006.

[18] U. M. Sainju, B. P. Singh, and S. Yaffa, "Soil organic matter and tomato yield following tillage, cover cropping, and nitrogen fertilization," Agronomy Journal, vol. 94, no. 3, pp. 594-602, 2002. 